\title{
Gender, Race, and Fortunes in the English East India Company's 'Familial Proto-State': The Evidence of Scottish Wills and Testaments C.1740-C.1820
}

\author{
Andrew MacKillop \\ University of Glasgow
}

\begin{abstract}
The family unit has become an important lens for investigating the social, gendered, and racial dimensions of early British imperialism in Asia. Using evidence derived from wills and testaments registered by Scots at the English East India Company's settlements between 1740 and 1820, this article explores how colonial wealth was redistributed. In doing so it reconsiders how families and kinship acted as both a transhemispheric connection between Europe and the Indian Ocean World and a disruptor of social, gendered, and racial dynamics.

It queries arguments that family boundaries could be porous enough to incorporate mixed-race children resulting from relationships between Europeans and local women. Analysis of overall patterns of wealth allocation, rather than individual family case studies, reveals a clear tendency to separate or 'silo' such children. Offspring born to local women received far less than family back in Scotland and were usually left in the place of their birth. Families in Scotland stressed a political economy of profit remittance and discouraged the creation of new obligations to children and local women. Considerable sums were instead allocated to female relatives. One result of the policing of extended family boundaries was a heightening in pre-1820s Scottish society of colour consciousness and racialised notions of identity. In this way, the Indian Ocean World, just as surely as better-known processes such as the Atlantic slave trade, contributed a practical and immediate set of imperatives driving new concepts of race and racialisation in Enlightenment era Scotland.
\end{abstract}

(C) Andrew MacKillop. This is an Open Access article distributed under the terms of the Creative Commons License CC BY NC SA, which permits users to share, use, and remix the material provided they give proper attribution, the use is noncommercial, and any remixes/transformations of the work are shared under the same license as the original. 


\section{INTRODUCTION}

Shifting trends in global history have made different scales of analysis relevant in new ways. One example of this development is the use of micro-level perspectives to better understand global processes. ${ }^{1}$ A manifestation in British imperial studies of this seemingly counter-intuitive approach is what might best be called the familial turn. Through the work of scholars such Durba Ghosh, Margot Finn and Emma Rothschild, the family unit has become a productive route into rethinking some of the socio-economic and cultural assumptions shaping early modern colonialism in Asia. ${ }^{2}$ Finn's reconstruction of the economic, social and cultural strategies of empire-service families highlights the significance of private and personal, as opposed to state and public, priorities in the English East India Company's [EIC] raj from c. 1780 to c. 1830. The result is a transformative, and still to be fully investigated, re-inscribing of the early colonial regime as a 'familial proto state.' This quasi-privatised version of empire stresses how national and racial boundaries were regulated through a form of familial economy as much as by official policies or ideologies of Asian otherness and race. ${ }^{3}$

The familial turn recalibrates aspects of global expansion, the protean nature of the colonial state, and the evolving character of long eighteenth-century race discourse. One incidental effect of this reframing is the foregrounding of Scottish networks active across the Indian Ocean World (IOW) from c. 1740 to c. 1820. Reconsideration of the ongoing importance of kinship as a trust mechanism among merchants and mariners operating between India, China and Europe utilises the examples of the Lennox of Campsie family and the careers of three sojourners from Scotland. ${ }^{4}$ Rothschild and Finn similarly rely on Scottish service gentry as exemplars of their arguments. It should be stressed that the Scottishness of these families is a decidedly secondary consideration to the wider points being made in these case studies. Yet the availability of such examples indicates how

\footnotetext{
${ }^{1}$ Miles Ogborn, Global Lives: Britain and the world, 1550-1800 (Cambridge: Cambridge University Press, 2008), 10-15; David Veevers, "Inhabitants of the universe": Global families, kinship networks, and the formation of the early modern colonial state in Asia," Journal of Global History, 10 (2015), 101-3.

${ }^{2}$ Durba Ghosh, Sex and the Family in Colonial India: The making of empire (Cambridge: Cambridge University Press, 2006); Margot Finn, "Anglo-Indian lives in the later eighteenth and early nineteenth centuries," Journal for EighteenthCentury Studies, 33 (2010), 49-65; Emma Rothschild, The Inner Lives of Empires: An eighteenth-century history (Princeton: New Jersey, 2011), 1-58.

${ }^{3}$ Margot Finn, "Family formations: Anglo-India and the familial proto-state," in Structures and Transformations in Modern British History, eds. David Feldman and Jon Lawrence (Cambridge: Cambridge University Press, 2011), 100-17.

${ }^{4}$ B. R. Tomlinson, "From Campsie to Kedgeree: Scottish enterprise, Asian trade and the Company Raj," Modern Asian Studies, 36 (2002), 769-91; Jessica Hanser, Mr Smith Goes to China: Three Scots in the making of Britain's global empire (New Haven: Yale University Press, 2019), 7-10.
} 
Scots formed an increasingly prominent, if always minority, presence among the European populations of the EIC's ports and outposts. ${ }^{5}$

By adapting and challenging aspects of the proto-familial state framework, this article continues the use of Scottish evidence in wider debates. It does so in three distinct but overlapping areas. The first relates to the regulation of gender and race in the early colonial order in South Asia and in Scotland. The emergence of a substantial mixed-race community in the Company's main settlements is understood to have been shaped by a conflicting, unstable and constantly evolving intersection of demographic, economic, religious, social and ultimately racial factors. ${ }^{6}$ Indrani Chatterjee and Durba Ghosh have transformed understandings of where such negotiations took place in an Indian context, stressing the central role of household, gendered, sexual, racial, and legal relations between European men and South Asian women during the EIC's raj from c.1750 to c.1830. There is a consensus that these domestic and intimate arrangements facilitated the ongoing 'creation of colour' and associated racialised and gendered hierarchies. There is less agreement, however, around the levels of agency available to Asian women and their use of patriarchal obligation and formal legal channels as a means of advancing their interests and those of their children. ${ }^{7}$

While in no way underestimating the central importance of race and colour, Finn questions the consistent and predominant influence of these factors by placing an equal emphasis on social status and family reputations. An analysis of two colonial service families, the Munros of Glasgow and the Elliots of Minto, argues that perceived social value and the potential for gentility played as important a role as colour and race in determining attitudes towards mixed-race children. ${ }^{8}$ What remains unclear is the extent to which the blurring of familial and racial boundaries outlined by Finn formed a routine or

\footnotetext{
${ }^{5}$ G. K. McGilvary, East India Patronage and the British State: The Scottish elite and politics in the eighteenth century (London: Tauris Academic Studies, 2008), 48-229; Andrew Mackillop, "Locality, nation and empire: The Scots in Asia, c.1695-1813," in The Oxford History of the British Empire: Scotland and the British Empire, eds. John M. MacKenzie and T. M. Devine (Oxford: Oxford University Press, 2011), 54-83; T. M. Devine and Angela McCarthy, "Introduction: The Scottish experience in Asia, c.1700 to the present: Settlers and sojourners', in The Scottish Experience in Asia, c. 1700 to the Present: Settlers and sojourners, eds. T. M. Devine and Angela McCarthy (Cham, CH: Palgrave-MacMillan, 2017), 1-21.

${ }^{6}$ Christopher J. Hawes, Poor Relations: The making of a Eurasian community in British India, 1773-1833 (Richmond: Curzon, 1996), 4-13.

${ }^{7}$ Indrani Chatterjee, "Colouring subalternity: Slaves, concubines and social orphans in early colonial India," in Subaltern Studies, X: Writings on South Asian History and Society, eds. Gautam Bhadra, Gyan Prakash and Susie Tharu (New Delhi: Oxford University Press, 1999), 51-63; Durba Ghosh, "Making and un-making loyal subjects: Pensioning widows and educating orphans in early colonial India," Journal of Imperial and Commonwealth History, 31 (2003), 1-23; Ghosh, Sex and the Family in Colonial India, 133-205.

${ }^{8}$ Finn, “Anglo-Indian lives," 59-61; Finn, "Family formations," 104-111.
} 
an atypical feature of the domestic arrangements created by Europeans, Scots included, in colonial era Asia. A survey of wills and testaments registered at Bombay, Madras and Calcutta by Scots can reveal embedded attitudes among sojourners to these questions of race, colour, class, gender, and geographies of belonging. Recovering general patterns establishes the typicality or otherwise of the family case studies. Although wills and the other legal documentation generated by colonial bureaucracy present problems of selective silence, representativeness, and reproducing hierarchies of power, it is an established methodology for examining the financial, social, and cultural practices of Europeans in Asia. ${ }^{9}$

Besides the interplay of race, colour, gender and class, there is the question of how European sojourners and their families regulated internal 'frictions' over cohabitation choices and the dispersal of profits acquired in Asia. ${ }^{10}$ Disputes over kinship boundaries and allocation of resources became particularly sensitive when a sojourner's decease or return home forced a reckoning over obligations to local women and the children produced by such relationships. The existence of a parallel mixed-race family could induce considerable anxieties among both sojourners and their relations in Europe, although usually for different reasons. ${ }^{11}$ Recovering the nature of these frictions and what they reveal about the socio-cultural foundations of the proto-familial state is the second theme considered using evidence from Scottish testaments.

The article's final concern relates to the ways in which these unstable familial dynamics contributed to a heightened consciousness of colour and ideas of an innate, as opposed to cultural, theological, or environmental understanding of race in Enlightenment-era Scotland ${ }^{12}$ The formation of these new attitudes was driven by a range of developments, including the involvement by Scots of all social classes in slaveryrelated transatlantic economies. The coercive displacement of native American peoples and a reliance on the mass enslavement of Africans and their descendants were defining features of the Atlantic World. A seminal cultural response to these troubling

\footnotetext{
${ }^{9}$ Durba Ghosh, "Decoding the nameless: Gender, subjectivity, and historical methodologies in reading the archives of colonial India," in A New Imperial History: Culture, identity, modernity, 1660-1840, ed. Kathleen Wilson (Cambridge: Cambridge University Press, 2004), 267-316; Ghosh, Sex and the Family, 109-10, 136-47.

${ }^{10}$ Margot C. Finn, "Frictions' d'empire: Les réseaux de circulation des successions et des patrimonies dans la Bombay coloniale des années 1780, » Annales: histoire, sciences sociale, 65 (2010), 1196-205; Ghosh, Sex and the Family, 113-21. ${ }^{11}$ Margot C. Finn, "Slaves out of context: Domestic slavery and the Anglo-Indian family, c. 1780-1830," Transactions of the Royal Historical Society, 19 (2009), 190-92; William Dalrymple, White Mughals: Love and betrayal in eighteenthcentury India (London: HarperCollins, 2002), 186-90, 234-45; Ghosh, Sex and the Family, 130-1.

${ }^{12}$ Colin Kidd, "Ethnicity in the British Atlantic world, 1688-1830," in A New Imperial History, ed. Wilson, 262-3; Nicholas Hudson, "From 'nation' to 'race': The origin of racial classification in eighteenth-century thought," Eighteenth-Century Studies, 29 (1996), 247-64.
} 
characteristics of the modern 'commercial' society was the development of elite and popular attitudes that attached increasingly rigid and pejorative meanings to race and colour. This racialisation of other peoples and cultures acted as an explanation of, and justification for, settler colonialism and enslavement. The central place of slavery and its related commodities in the Atlantic empire was the single most significant cause of the racialisation of early modern Scottish and British society. ${ }^{13}$ To this pervasive economic influence can be added the work of intellectuals like David Hume and the University of Edinburgh's leading role in the replacement of biblical and family lineage-based concepts of nation and race with biologically essentialised understandings of human difference. Even the work of the sentimental novelists, such as Henry MacKenzie, popularised new readings of racialised distinctions. ${ }^{14}$ The extent to which Scotland's racialisation was shaped by the intimate, domestic politics of mixed-race families from Asia when compared with these other dynamics should not be over-exaggerated. Yet while only one thread in a wider weft and weave of factors, the importance of the eastern half the Empire has been noticeably underestimated in assessments of how racial thinking evolved in a provincial society like Scotland. ${ }^{15}$

The nature of the country's migratory connections with Asia in this period went well beyond abstract matters of philosophy, literary trends, or debates in the natural sciences. The re-reading of social priorities and economic motivations through the familial turn points to the everyday, immediate, and even intimate foundations of ideas of colour and race in early colonial Asia. ${ }^{16}$ The frictions over who ought to be included in transnational family units and on what basis brought such considerations back into Scottish localities and family matters in very personal and pressing ways. These backflows raise important questions about the transhemispheric boundaries of the IOW and the way such interconnections informed developments across the whole of Europe, not just its key

\footnotetext{
${ }^{13}$ Léon Poliakov, "Racism from the enlightenment to the age of imperialism', in Racism and Colonialism: Essays on ideology and social structure, ed. R. Ross (Leiden: Springer, 1982), 55-63; Silvia Sebastiani, The Scottish Enlightenment: Race, gender, and the limits of progress, trans. Jeremy Carden (New York: Palgrave Macmillan, 2013), 10-14; Andre C. Willis, "The impact of David Hume's thoughts about race for his stance on slavery and his concept of religion," Hume Studies, 42 (2016), 214.

${ }^{14}$ Colin Kidd, The Forging of Races: Race and scripture in the Protestant Atlantic world, 1600-2000 (Cambridge: Cambridge University Press, 2006), 19; Bill Jenkins, "Race before Darwin: Variation, adaptation and the natural history of man in post-Enlightenment Edinburgh, 1790-1835," British Journal for the History of Science, 53, 3 (2020), 333-50; James D. Lilley, "Henry Mackenzie's ruined feelings: Romance, race, and the afterlife of sentimental exchange," New Literary History, 38, 4 (2007), 649-66.

${ }^{15}$ J. Rendall, "Scottish Orientalism: From Robertson to James Mill," Historical Journal, 25 (1982), 43-69; Geoffrey Carnell, "Robertson's and contemporary images of India," in William Robertson and the Expansion of Empire, ed. Stewart J. Brown (Cambridge: Cambridge University Press, 1997), 210-30.

${ }^{16}$ Onni Gust, Unhomely Empire: Whiteness and belonging, c. 1760-1830 (London: Bloomsbury, 2020), 7-18.
} 
imperial centres. ${ }^{17}$ Moreover, these familial and financial concerns impacted a broad social range of Scots, including EIC merchants, military officers, mariners, and ordinary soldiers. Using wills and testaments to survey the division of colonial wealth along gendered, racial and familial lines enables a greater awareness of the means by which links to Asia informed new trends in racialist thinking in Enlightenment Scotland.

\section{SAMPling Wills ANd Testaments}

One obvious demographic indicator of the EIC's changing character in the long eighteenth century was the growing number of individuals from the non-English regions of the British and Irish Isles in its employment or operating under its protection as private merchants, mariners, retailers and artisans. ${ }^{18}$ Along with an influx of Irish personnel, Scots ensured the EIC became a more genuinely British-Hiberno institution than the Union state back in Europe. ${ }^{19}$ Once in the East Indies, Scots differed little if at all from other European nationals in their economic motives and socio-cultural attitudes to local people and culture. This is hardly surprising. Over two hundred years of contact and interaction meant the tone of relations between Asians and Europeans was well established long before Scots appeared in any substantial numbers. ${ }^{20}$ As Asia attracted more and more sojourners from the 'provincial' areas of the British and Irish Isles, familial-based trust mechanisms also transferred eastwards. ${ }^{21}$ The use of extended family units to conduct the long distance commerce so characteristic of the East Indies is more usually associated with the trading diasporas of the Armenians or the Chinese communities in South East Asia. ${ }^{22}$ The

\footnotetext{
${ }^{17}$ Jan de Vries, "The limits of globalisation in the early modern world," Economic History Review, 63 (2010), 711-14.

${ }^{18} \mathrm{H}$. V. Bowen, The Business of Empire: The East India Company and Imperial Britain, 1756-1833 (Cambridge: Cambridge University Press, 2006), 272; Seema Alavi, The Sepoys and the Company: Tradition and transition in northern India, 1770-1830 (Oxford: Oxford University Press, 1995), 5-32; P. J. Marshall, "Masters and Banians in eighteenthcentury Calcutta," in The Age of Partnership: Europeans in Asia before Dominion, eds. Blair B. Kling and M. N. Pearson (Honolulu: University of Hawaii Press, 1979), 191-213; Om Prakash, "From market-determined to coercion-based: Textile manufacturing in eighteenth century Bengal," in How India Clothed the World: The world of South Asian textiles, 15001800, eds. Giorgio Riello, Tirthankar Roy and Om Prakash (Boston: Brill, 2009), 224-51.

${ }^{19}$ P. J. Marshall, "British society in India under the East India Company," Modern Asian Studies, 31 (1997), 90-1.

${ }^{20}$ Sanjay Subrahmanyam, Europe's India: Words, people, empires, 1500-1800 (Cambridge, MA: Harvard University Press, 2017), 144-70.

${ }^{21}$ For the utility of 'provinces' as a framework for exploring the British and Irish Isles' complexity in the context of empire, see: Bernard Bailyn and Philip D. Morgan, "Introduction," in Strangers within the Realm: Cultural margins of the first British Empire, eds. Bernard Bailyn and Philip D. Morgan (Chapel Hill: University of North Carolina Press, 1991), 20-31; H. V. Bowen, Elites, Enterprise and the Making of the British Overseas Empire, 1688-1775 (London: Palgrave Macmillan, 1996), 154-5.

${ }^{22}$ Sebouh Aslanian, "Social capital, 'trust' and the role of networks in Julfan trade: Informal and semi-formal institutions at work," Journal of Global History, 1 (2006), 383-402; Bhaswati Bhattacharya, "Making money at the blessed place of Manila: Armenians in the Madras-Manila trade in the eighteenth century," Journal of Global History, 3 (2008), 1-20;
} 
European presence, by contrast, is typically framed in terms of involvement in formal corporate and colonial state infrastructures. Yet as the work of Finn demonstrates, Europeans appreciated the value of kin networks in underpinning reliable profit-making activities. This explains why, as Scots began arriving in ports such as Bombay, Madras, Calcutta and Benkulen, other Scots quickly followed in their wake. ${ }^{23}$

The use of kinship links proved a highly effective economic tactic and helped to ensure that a relatively underdeveloped society on the north west edge of Europe could increasingly access one hemisphere of the emerging world economy. ${ }^{24}$ One indicator of the corporation's diversifying European workforce is the number of wills registered by Scots at the mayor courts of the EIC's key settlements. ${ }^{25}$ Table 1 summarises the total for Bengal from 1780 to 1800 , with a further two sample years in 1805 and 1810, for the Madras presidency from 1753 to 1810, and for the Bombay presidency from 1740 to 1810. As well as providing a summary of the financial assets listed in wills registered by Scots, the equivalent Irish and Welsh testament numbers are included to help contextualise the Scottish profile. A Scot is defined here as an individual who travelled to Asia and either died there or returned to Europe after lodging a testament at one of the Company courts. Inclusion in the following tables does not mean individuals were necessarily resident in the East Indies at the point of death or alternatively domiciled back in Scotland. The only criterion for inclusion is that a testament must show clear evidence that the testator originated from Scotland. In his will of 1800, for example, Lieutenant William Stuart of the Bengal army did not at any point refer to his Scottishness. As with many other individuals incorporated into the tables, his origins are revealed through the naming of executors and their place of residence, in this case, Stuart's brother, a lawyer in Edinburgh and the listing of other family residing north of the border. ${ }^{26}$

Defining Scots by this method undoubtedly lowers the overall percentages shown in the various tables. A substantial number of testaments such as that of the free mariner, Robert Abercromby in Bombay in 1748 or Captain Archibald Blair at Madras in 1761 are

Kenneth Pomeranz and Steven Topik, The World and Trade Created: Society, culture and the world economy, 1400 to the Present (New York: Routledge, 2018), 11-15, 44.

${ }^{23}$ India Office Records, British Library, London (hereafter: IOR) O/5/26-27, 30-31; McGilvary, East India Patronage, 21031.

${ }^{24}$ A. G. Hopkins, "The history of globalisation - and the globalisation of history?," in Globalisation in World History, A. G. Hopkins (London: Pimlico, 2002), 25-8; Andrew Phillips, "The global transformation, multiple early modernities, and international systems change," International Theory, 8 (2016), 481-8.

${ }^{25}$ A. Mackillop, "Europeans, Britons and Scots: Scottish sojourning networks and identities in Asia, c. 1700-1815," in A. McCarthy (ed.), A Global Clan: Scottish migrant networks and identities since the eighteenth century (London: Tauris, 2006), 19-47.

${ }^{26}$ IOR, L/AG/34/29/12/42. 
excluded. ${ }^{27}$ While name evidence points to these men being Scots, the documentation does not contain explicit evidence of place of origin. This was a feature common to hundreds of wills, especially those of ordinary sailors and seamen. This characteristic of the source material means that while Table 1 represents the bare minimum of the respective national totals, the sample is robust. The figures also need to be assessed against the fact that a range of individuals, including other European nationals and prominent local Asian residents, utilised the mayor courts. The diversity of those registering their legal affairs substantially inflates the overall total against which the Scottish, Irish and Welsh share is assessed. ${ }^{28}$ The fact that the Irish made up between $4 \%$ and $5 \%$ of all wills and Scots $10 \%$ indicates their considerable numeric presence among the locally resident British and Irish Isles sojourning population.

\begin{tabular}{|c|c|c|c|c|c|}
\hline Presidency & Total & Irish & Welsh & Scots & Assets (Scots wills) \\
\hline Bengal & 1,299 & $60(4.6 \%)$ & $11(0.8 \%)$ & $142(10.9 \%)$ & $£ 314,322.00$ \\
Bombay & 1,092 & $48(4.3 \%)$ & $4(0.3 \%)$ & $112(10.2 \%)$ & $£ 140,408.00$ \\
Madras & 1,567 & $82(5.2 \%)$ & $7(0.4 \%)$ & $167(10.6 \%)$ & $£ 305,949.00$ \\
& & & & & \\
Total & $\mathbf{3 , 9 5 8}$ & $\mathbf{1 9 0 ( 4 . 8 \% )}$ & $\mathbf{2 2}(\mathbf{0 . 5 \%})$ & $\mathbf{4 2 1}(\mathbf{1 0 . 6 \% )}$ & $\mathfrak{£ 7 6 0 , 6 7 9 . 0 0}$ \\
\hline
\end{tabular}

Table 1: Irish, Scots, and Welsh Wills \& Testaments: Bengal, Bombay and Madras, 1740-1810 (IOR, P/328/60-64, 79; P/416/80-98; L/AG/34/29/185-210; L/AG/34/29/341-43; L/AG/34/29/4-12, 17 \& 22)

Several trends are apparent. The first is the noticeable consistency of the national profiles across the three main settlements. The more obvious disparity is between the different non-English nationalities. By what is an admittedly selective indicator, Scots formed a consistently greater presence than either the Irish or Welsh among those with sufficient material resources to make it worth their while registering a will. This preponderance was evident across the Company's three main settlements, with significantly more than twice as many Scottish wills registered compared to the Irish, and with the Welsh profile surpassed by a factor of nearly twenty to one.

Care is needed, however, with this type of data. While an invaluable qualitative source, wills hide as much as they reveal. ${ }^{29}$ Despite the clear pattern in Table 1, there were in fact many more Irish than Scots in colonial South Asia throughout this period. This

\footnotetext{
${ }^{27}$ IOR, P/416/83, p. 7; P/328/61 [1761], 11.

${ }^{28}$ Ghosh, Sex and the Family, 170-1; Ghosh, "Making and un-making loyal subjects," 4; Mattison Mines, "Courts of law and styles of self in eighteenth-century Madras: From hybrid to colonial self," Modern Asian Studies (2001), 34-7.

${ }^{29}$ Bridget J. Crawford and Anthony C. Infanti, "A critical research agenda for wills, trusts and estates," Real Property, Trust and Estate Law Journal, 49 (2014), 319-21.
} 
preponderance arose from the Company's post-1750 reliance on recruits from Ireland for the European regiments of the Bengal, Bombay and Madras armies. ${ }^{30}$ While some of these low-ranking personnel did register their legal affairs, the vast majority did not and so are rendered invisible in this sector of the colonial bureaucracy. ${ }^{31}$ The vast majority of Scots registering such documentation were men, and were in the main artisans, retailers, maritime officers as well as middling or high ranking mercantile, military, medical and civil service professionals. The Figures in Table 1 confirm that Scots congregated disproportionately in those areas of the colonial economy and state which generated assets sufficient enough to warrant registering a will.

Many of the testators died shortly after registering their affairs, while others registered their testaments as part of their preparations for an imminent return to Europe. Executors or trustees were usually chosen based on a combination of family members back in Europe and friends and professional associates from the deceased's time in Asia. The long-distance mobility of testators was matched by that of the documentation itself, which often crossed hemispheres and multiple legal jurisdictions. The capacity to navigate different legalistic frameworks was a key feature of society and economy across the IOW. ${ }^{32}$ But this legal pluralism had a particular resonance for Scots, who routinely sought to move their property and profits through the Company's jurisdiction, into the English legal system via the Probate Court of Canterbury, and finally to the Scottish courts. On 12 May 1798, Lieutenant-colonel William MacKintosh registered his will at Calcutta, and by 3 May 1799 it had been lodged at Canterbury. By the time of his death in 1803 it existed in a third, distinctively Scottish form in the books of the Edinburgh Commissary Court. ${ }^{33}$ Tracing the legal genealogy of wills in this way enhances the methodology used to designate an individual definitively as a Scot.

\footnotetext{
${ }^{30}$ Thomas Bartlett, “The Irish soldier in India, 1750-1947," in Ireland and India: Connections, comparisons, contrasts, eds. Michael Holmes and Denis Holmes (Dublin: Folens, 1997), 12-28; Barry Crosbie, Irish Imperial Networks: Migration, social communication and exchange in nineteenth-century India (Cambridge: Cambridge University Press, 2012), 68-98.

${ }^{31}$ For examples of ordinary soldier and sailor wills, see: IOR, P/328/60 [1757], 126-127; P/328/61 [1762], 61-62; L/AG/34/29/342 [7 December 1798-13 Dec. 1802], 1-5, 9-10, 31.

${ }^{32}$ Lauren Benton, "Colonial law and cultural difference: Jurisdictional politics and the formation of the colonial state," Comparative Studies in Society and History, 41 (1999), 563-588; Lauren Benton and Richard J. Ross, "Empires and legal pluralism: Jurisdiction, sovereignty and political imagination in the early modern world," in Legal Pluralism and Empires, 1500-1850, eds. Lauren Benton and Richard J. Ross (New York: New York University Press, 2013), 1-18.

${ }^{33}$ IOR, L/AG/34/29/6 [1789], 17; IOR L/AG/34/29/12/6; National Records of Scotland, Edinburgh (hereafter: NRS), CC8/8/134: Lt-Col. William Macintosh, Edin CC, pp.730-43.
} 


\section{FAMily Fortunes?}

In these documents can be traced some of the familial, financial, and cultural concerns of sojourners active during the early decades of the East India Company's raj and in the wider system of intra-Asian trade. Testaments reveal the material, gendered, emotional and racial dynamics that shaped the dispersal of both large and small fortunes. The total of $£ 760,679$ represented a major augmentation of individual and family liquidity and represents the real price equivalent in 2020 of $£ 61.87$ million. ${ }^{34}$ These profits were secured by a small minority of the total number of Scots who journeyed to Asia either as Company personnel or on their own private account. As with any findings derived from testaments, the information in the tables is unrepresentative in certain respects. Most Europeans never made a will, while many sojourners either failed in their financial objectives and returned home or died before they could secure any meaningful assets. ${ }^{35}$ Yet the expectation created by widely known stereotypes of the 'Orient's' fabulous wealth ensured that individuals and social networks from Europe continued to be attracted to Asia. Scots were no different, experiencing both high death rates and highly variable patterns of wealth accumulation. ${ }^{36}$

Viewing the wills collectively enables the recovery of general trends in wealth allocation. In these patterns can be found the underlying but powerful social, gendered and race dynamics that helped determine the transhemispheric character and cultural tone of the 'familial proto-state.' Tables 2 and 3 summarise the dispersal of wealth and confirm stark differences between the prioritising of family in Europe compared to the local families created through household and sexual relationships with Asian women. Table 2 covers wealth allocated in wills registered at Calcutta, Bombay and Madras which was assigned explicitly to family members back in Europe. In the case of Scots, this was usually to relations still in Scotland but included those living in England (often in London) or, less commonly, elsewhere in the Empire. The bulk of wealth recorded in all testaments traced to Scots - £525,196 (69\%) - was returned to Europe, with the distribution showing that a sojourner's siblings were conspicuous recipients rather than wives, mothers or

\footnotetext{
${ }^{34}$ The modern equivalent is derived from a calculation related to Retail Price Indexes from the Measuring Worth Foundation website. See https://www.measuringworth.com/calculators/ukcompare/relativevalue.php [Accessed: 7 Dec. 2021].

${ }^{35}$ P. J. Marshall, East Indian Fortunes: The British in Bengal in the eighteenth century (Oxford: Clarendon Press, 1976), 218-9; D. Arnold, 'India's place in the tropical world, 1770-1930," Journal of Imperial and Commonwealth History, 26 (1998), 6-11.

${ }^{36}$ IOR, P/328/63, 106-9; L/AG/34/29/4 [1780], 133-43. See also: A. Mackillop, "The Highlands and the returning nabob: Sir Hector Munro of Novar," in Emigrant Homecomings: The return movement of emigrants, 1600-2000, ed. Marjory Harper (Manchester: Manchester University Press, 2005), 242-56.
} 
fathers. The fact that most sojourning European men in Asia in this period were unmarried, in an official sense at least, partly explains the relatively small amount left to legally recognised wives and children (either at home or in Asia). ${ }^{37}$

Table 3 shows monies allocated to relations, associations, local women and children noted as resident in Asia at the time of the will's registration. As such it provides evidence of how much colonial wealth did not circulate back to the sojourner's original family group.

\begin{tabular}{|c|c|c|c|c|c|c|c|c|}
\hline & Wife & \multicolumn{2}{|c|}{ Children } & \multicolumn{2}{c|}{ Parents } & \multicolumn{2}{c|}{ Siblings } & Kin \\
\hline & & Female & Male & Mother & Father & Sisters & Brothers & \\
\hline Wills & 33 & 20 & 19 & 80 & 68 & 141 & 130 & 92 \\
& $(7.8 \%)$ & $(4.7 \%)$ & $(4.5 \%)$ & $(19 \%)$ & $(16.1 \%)$ & $(33.4 \%)$ & $(30.8 \%)$ & $(21.8 \%)$ \\
\hline Total & $£ 38,757$ & $£ 50,225$ & $£ 19,092$ & $£ 24,695$ & $£ 20,862$ & $£ 135,625$ & $£ 172,660$ & $£ 63,280$ \\
& $(5 \%)$ & $(6.6 \%)$ & $(2.5 \%)$ & $(3.2 \%)$ & $(2.7 \%)$ & $(17.8 \%)$ & $(22.6 \%)$ & $(8.9 \%)$ \\
\hline
\end{tabular}

Table 2: The 'Familial Proto-State' (Europe), 1740-1810 (IOR, P/328/60-64, 79; P/416/80-98; L/AG/34/29/185-210; L/AG/34/29/341-43; L/AG/34/29/4-12, 17 \& 22)

\begin{tabular}{|c|c|c|c|c|c|c|c|c|}
\hline & Wife & $\begin{array}{c}\text { 'Housekeeper'/ } \\
\text { 'Girl' }\end{array}$ & \multicolumn{2}{|c|}{ Children } & \multicolumn{2}{|c|}{ Associates } & Servants & Slaves \\
\hline & & & Female & Male & Professional & Kin & & \\
\hline Wills & 15 & 61 & 58 & 48 & 42 & 31 & 12 & 13 \\
& $(3.5 \%)$ & $(14.4 \%)$ & $(13.7 \%)$ & $(11.4 \%)$ & $(9.9 \%)$ & $(7.3 \%)$ & $(2.8 \%)$ & $(3 \%)$ \\
\hline Total & $£ 4,185$ & $£ 18,634$ & $£ 61,137$ & $£ 79,109$ & $£ 26,780$ & $£ 37,711$ & $£ 2,985$ & $£ 270$ \\
& $(0.5 \%)$ & $(2.4 \%)$ & $(8.1 \%)$ & $(10.3 \%)$ & $(3.5 \%)$ & $(4.9 \%)$ & $(0.3 \%)$ & $(0.03 \%)$ \\
\hline
\end{tabular}

Table 3: The 'Familial Proto-State' (Asia), 1740-1810 (IOR, P/328/60-64, 79; P/416/80-98; L/AG/34/29/185-210; L/AG/34/29/341-43; L/AG/34/29/4-12, 17 \& 22)

\section{GENDER IN WiLls AND TeStAMENTS}

Considerations of gender clearly influenced the flow of profits back to Scotland, with a sojourner's mother, sister, and female children generally receiving greater sums than either sons or fathers. The effect of this allocation pattern on gender dynamics was ambiguous. On the one hand, women relatives were favoured in ways that created greater levels of material and financial security. However, the dispersal of monies could also work to consolidate patriarchal authority. Male family members nearly always served as executors and were expected under the terms of the will to distribute the proceeds to the

\footnotetext{
${ }^{37}$ Julia Schleck, "The marital problems of the East India Company," Journal for Early Modern Cultural Studies, 17, 3 (2017), 83-6; Hawes, Poor Relations, 12-16.
} 
deceased's remaining family. Typical in this respect was the 1771 Madras testament of Ensign George Taylor. After gifting $£ 246$ to his brother, John, an Edinburgh lawyer, George asked that the sum be divided equally into three parts: one to John, and the other portions to another brother and a sister. ${ }^{38}$ This was a common legal arrangement and gave considerable discretion to male family members by leaving them in control of bequests. Brothers were often chosen for this role rather than fathers for the simple reason they were more likely to still be alive and able to complete the deceased's final wishes. ${ }^{39}$ These practicalities also explain why the amount left to brothers listed in Table 2 was the single largest sum remitted to Europe, despite these testaments forming a smaller percentage $(30.8 \%)$ than those noting sisters as beneficiaries (33.4\%).

If, as Durba Ghosh has emphasised, the development of a reputation for responsible patriarchy was a key aim of European men in their treatment of Asian women and children, the same was true of the assumptions shaping remittances to Europe. ${ }^{40}$ The gendered dimension of this process produced what might at first appear to be inconsistent trends. On the one hand, they reinforced patriarchy through the funnelling of assets to male executors while, on the other, they generated pressures to allocate assets to female relatives. ${ }^{41}$ As shown in Table 2 , the provision of specific amounts to close female kin was a structural characteristic of the proto-familial state economy and a feature of no less than $60 \%$ of all the sampled Scottish wills. A widespread expectation clearly existed which gave mothers, sisters and nieces a legitimate claim on wealth made in Asia. ${ }^{42}$ Indeed, at over one third of all testaments, sisters were more likely to be explicitly identified as a recipient than any other family member, fathers and brothers included.

Some bequests could be substantial and enabled female recipients to either join or consolidate their position in the affluent levels of local society. William Balfour, a Madras civil servant, left major sums to his sisters upon his death in 1793. His will underlines how India-made profits reinforced patriarchal hierarchies in northern Europe while endowing female relatives with socially transformative amounts of wealth. Elizabeth, who was already married, received $£ 5,000$, while Anne, who was unmarried, received $£ 7,000$. The

\footnotetext{
${ }^{38}$ IOR, P/328/63 [1772], 101-2, 118-9.

${ }^{39}$ Kinross House, Graham of Kinross Papers, Box Graham Papers, $2^{\text {nd }}$ Series, Nos 51-126, Bundle 57: Calcutta, 21 Aug. 1776: Thomas Graham to George Graham; NRS GD137/1131: Edinburgh, 21 Dec. 1774: David Scrygmeour to Alexander Scrygmeour; NRS GD137/1142: Fort Marlborough, 31 July 1778; IOR L/AG/34/29/185 [1780], 164-5.

${ }^{40}$ Ghosh, Sex and the Family, 107-32; Thomas Williamson, The East India Vade-Mecum: Or the complete guide to gentlemen intended for civil, military, or naval services of the honourable East India Company Vol.1 (London: Black, Parry, and Kingsbury, 1810), 452-3.

${ }^{41}$ For testaments in which the sojourner provided support to a woman from his place of origin and with whom he had a child outside of marriage, see: IOR L/AG/34/29/8/27a; IOR L/AG/34/29/194, 221-2.

${ }^{42}$ IOR P/328/62 [1764], 33. For a similar will in Bombay, see: IOR, P/416/83 [1748], 7.
} 
significance of these gifts can be appreciated when set against the fact that the parish of Markinch, in which the Balfour family estate of Balbirnie was located, had a total landed rental of 'upwards of $£ 5,000$ ' in $1794 .{ }^{43}$ Through such redistribution, the Company's early colonial regime in India played a role in consolidating the material basis and gendered dimensions of Scotland's genteel social and landed order.

Transhemispheric remittances also augmented the assets of women from far less affluent backgrounds. As a result, the benefits of the connection to Asia trickled down Scotland's social order and across its geographic regions. Assynt in Sutherland is not a locality usually associated with Britain's empire in the East Indies. Yet military service generated connections between this rural community and India. John MacKenzie from the farm of Ouldany served in the $73^{\text {rd }}$ Highland regiment. As an enlisted man he benefited from salary accumulation and prize money through his unit's involvement in the looting in 1799 of Srirangapatna, the capital of Mysore. While typical of the tens of thousands of men in the Company's garrisons or with British regiments sent east, MacKenzie was atypical in that he left a will in 1801 . He bequeathed $£ 400$ to his sister, Margarita, who still resided in Assynt. The significance of this amount becomes clear when set against the fact that in 1775 Ouldany's annual rental stood at $£ 30$, while only six years prior to MacKenzie's death the entire parish rented for $£ 1,000 .{ }^{44}$

The life changing nature of wealth remitted to places like Markinch or Assynt reveal the profound, if quotidian, social and gendered ramifications embedded in the patterns in Table 2. The broad geographic dispersal of monies was a noticeable characteristic of this familial remittance economy. Like Private John MacKenzie, Major John Munro originated from Sutherland, and his will too was proven at Madras in 1801. High rank, however, meant his legal and financial affairs encompassed a swathe of Scotland, with a noticeable emphasis on provision for his female relatives. Sisters in Sutherland and Caithness, an aunt in Edinburgh, and a female cousin in Greenock received monies ranging from $£ 100$ to $£ 800$. Associates in Orkney benefited, as did male relatives in Argyll and Edinburgh, who were expected to act as trustees and executors. ${ }^{45}$

The overlap between the authority of the Company's courts and informal webs of kinship was a central feature of the familial proto-state. As Table 2 demonstrates, the type

\footnotetext{
${ }^{43}$ IOR L/AG/34/29/195, 455-7; The Statistical Account of Scotland online service: https://stataccscot.edina.ac.uk:443/link/osa-vol12-p530-parish-fife-markinch [Accessed: 7 Dec. 2021]

${ }^{44}$ IOR L/AG/34/29/201, 270-2; R. J. Adam (ed.), John Home's Survey of Assynt (Edinburgh: T. \& A. Constable, 1960), 62; The Statistical Accounts of Scotland online service: https://stataccscot.edina.ac.uk:443/link/osa-vol16-p201-parishsutherland-assynt [Accessed: 7 Dec. 2021]. See also: IOR L/AG/34/29/343, 6-8.

${ }^{45}$ IOR L/AG/34/29/201, 276; IOR L/AG/34/29/202, 67-71.
} 
of donations Munro made to uncles, aunts, nephews, and nieces were sufficiently common that one in five of all testaments named kinsmen and kinswomen as beneficiaries. A sense of obligation to wider family extended to Asia, with sojourners often leaving some of their wealth to other relatives who had also journeyed eastward. Professional ties and loyalties meant merchants, surgeons or military officers often used their peers as Asia-based executors and beneficiaries, a fact which explains the $£ 26,780$ left to colleagues. Yet the influence of relocated kin ties meant that a greater sum of money $(£ 37,711)$ was left to relatives resident in India or at another of the Company's outposts. This pattern of mutual reliance reinforces Finn's emphasis on the centrality of private, family-based objectives among British and Irish personnel in Asia in the decades prior to c. $1830 .{ }^{46}$ Judicial authority and kinship influences complemented each other and facilitated global transfers of colonial wealth. The Company's legal machinery enabled wealth redistribution in ways that perpetuated wider kin-based, as opposed to nuclear, configurations of the family unit.

\section{Containing And Distancing RACE}

Beyond augmenting the financial and social standing of female relatives, implicit racial pressures shaped transoceanic familial economies. Compared to the sums allocated to legally recognised wives shown in Table 2, the amounts left to local women was significantly less. With official rates of marriage among sojourners so low, wives in Europe were evident in only $7.8 \%$ of all testaments and received only $5 \%$ of all enumerated wealth. Table 3, by contrast, confirms that domestic cohabitation with local women was common enough to be mentioned in one testament in seven. ${ }^{47}$ A variety of deliberately mundane and euphemistic titles such as 'housekeeper', 'girl', 'servant' and 'companion' were used to disguise the status and role of these women. Despite the fact they appeared in a significantly greater number of testaments - 61 compared to 15 - they were allocated only half the amount reserved for the much smaller number of legal wives. ${ }^{48}$ The stark financial difference indicates the attitude of Scots in Asia to ideals of patriarchy, gender and the racial boundaries of family.

Economic and material marginalisation did not prevent Asian women from attempting to exercise their agency. Ghosh has argued persuasively that the capacity to do

\footnotetext{
${ }^{46}$ Finn, "Family formations," 117.

${ }^{47}$ For wills deploying widely understood euphemisms to describe women in cohabiting and sexual relationships with the testator, see: IOR L/AG/34/29/15/57; IOR L/AG/34/29/17/4; IOR L/AG/34/29/204, 5-9; IOR L/AG/34/29/341 [1785], 74-5; IOR LAG/34/29/342 [1789], No. 23.

${ }^{48}$ Finn, "Slaves out of context," 186-8; Chatterjee, "Colouring subalternity," 56-7.
} 
so lay on a broad spectrum from the brutalising status of household and sexual slavery to the adroit use of patriarchal conventions as a means of securing legal and financial rights. ${ }^{49}$ Allowing for the ways in which legal documents silence the voices of subaltern actors such as South Asian women and their children, the evidence from wills left by Scots nonetheless demonstrates the limits of negotiation and autonomy. Along with other Europeans, Scots practiced forms of domestic slavery that encompassed the type of concubinage and sexual exploitation traced by Chatterjee. In December 1763 the will of Robert Erskine from near Dunfermline in Fife, the Company's diplomatic representative at Gwalior, was proven at Bombay. After 'freeing' 'his girl' and leaving her a bequest of $£ 125$, the testament noted she was pregnant and that the child was to be allocated $£ 500$ for its future welfare. ${ }^{50}$ The ambiguous nature of the arrangement was typical of the coded conventions used to acknowledge but also limit the financial, personal and cultural tensions generated by mixed-race relations. The substantial monetary gift of $£ 125$ points to a sense of obligation created through the existence of a physical relationship. Yet this woman's enslaved status left her with little or no choice in the matter.

The coercive and exploitative power relations inherent in these circumstances did not prevent some women from establishing interactions with European men based upon a degree of sensitivity towards their wellbeing and status. Lieutenant David Buchan of the Madras army, originally from Edinburgh, left $£ 260$ in 1809 to 'Beenbean Saib' for 'her faithful attachment.' Major Peter Cullen, son of the famous Dr William Cullen stressed that 'a native woman,' 'Noorisa Nissa,' should receive an annuity of $£ 150$ for the remainder of her life. This was an unusually substantial commitment, reiterated in the version of the will registered in the Scottish courts, and so known to Cullen's wife, who was left the bulk of his property. ${ }^{51}$ The emotive issue of separating offspring from their mothers by sending them back to Europe was addressed only intermittently in this type of legal documentation. It seems that on occasion patriarchal sensibilities extended to considering the emotional impact on women arising from such a decision. In 1800, the Madras army captain, William Oliphant left an unusually detailed set of thoughts on this issue. He stressed to his executors that they should attempt to persuade the unnamed mother into giving up her child: however, he made it clear she could not be compelled to

\footnotetext{
${ }^{49}$ Ghosh, Sex and the Family, 133-69.

${ }^{50}$ IOR J/1/1/, 53-6; IOR B/70, 539, 542-3; IOR P/416/94, 12-14; IOR P/416/92, 32-3.

${ }^{51}$ IOR L/MIL/9/111/197; IOR L/AG/34/29/209, 44; IOR L/AG/34/29/8/34; IOR CC8/8/131: Edinburgh Commissary Court: Major Peter Cullen, 333; V.C.P. Hodson, List of the Officers of the Army of Bengal, 1754-1834, I (London, 1927), 421-2.
} 
do so. ${ }^{52}$ In such brief and relatively rare explanations can be found some of the intimate dynamics that enabled local women to at least negotiate and exercise some agency.

Instances of financial support and emotional awareness support arguments that 'Orientalist' assumptions remained fluid enough to enable cross-cultural contact and some mutual respect between European men and South Asia women until the c. $1800 \mathrm{~s} .{ }^{53}$ But evidence from Scottish testaments points to the actions of Buchan or Cullen as noticeably atypical, even before the 1800s. It was far more common for Asian women to be left insignificant, even tokenistic amounts, less than $2.5 \%$ of all wealth cited in wills. Individual examples of emotional and social commitment cannot disguise the clear structural inequalities and systematic marginalisation of local women by most sojourning Scots.

The treatment afforded to mixed-race children is a particularly sensitive barometer of the tensions, ambivalences, and hardening race assumptions at the heart of families involved in sojourning to colonial-era Asia. Comparing the experiences of Alexander and Thomas Munro's offspring has enabled Finn to explore such dynamics. Mary was Alexander's European-Indian daughter, while Jessy was born out of marriage to Thomas and a Glaswegian woman. Education and socialisation in Scotland in the 1790s ultimately enabled Mary to secure a respectable marriage and a recognised family position despite her mixed-race background. In contrast, and despite her 'all white' origins, knowledge of her mother's relatively low social background worked against Jessy and meant she never obtained a similar material security or status. Class, not colour or race, was the key determinant in this instance. ${ }^{54}$

The effacement of race through social repositioning and permeable familial boundaries in the case of Mary Munro is echoed in some wills and testaments. In 1780 Lieutenant Robert MacMurdo of the Madras army stipulated that his two 'natural' children with a local woman were to be sent to an aunt in Edinburgh. Another child, born to a different 'girl,' 'Mootie' was similarly despatched to Scotland. MacMurdo clearly hoped his offspring could be accepted in the way that occurred with Mary Munro fifteen years later. Making use of kinship networks and the authority of the Company's courts in ways characteristic of the 'familial proto-state,' he arranged for his brother-in-law, a lawyer in Edinburgh, to administer a fund for his aunt. She was to have 'the maintenance and education of my children which I particular request may be the genteelest [sic] and

\footnotetext{
${ }^{52}$ IOR L/AG/34/29/201 [1800], 87.

${ }^{53}$ Dalrymple, White Mughals, 37-9.

${ }^{54}$ Finn, "Anglo-Indian lives," 58-63.
} 
also liberal that can be given them.' The Bombay surgeon, William Boag hoped a similar strategy would work for his daughter. The girl was born as a result of a sexual relations with an unnamed 'housekeeper;' less typical was the surgeon's injunction that his daughter be placed in the care of his brother-in-law, a Mr Clelland in Ayr, to ensure 'a virtuous, religious and genteel education. ${ }^{55}$ The emphasis on education as a means of integration aligns with Finn's analysis of how race could be managed, obviated and to some extent surmounted. But the insistent, anxious tone of both sets of instructions hint at how sojourners understood the challenges their children would face back in Europe.

Apprehensions over family reputations and likely long-term prospects shaped wider patterns of domestic arrangements for mixed-race children. Compared to the relatively small sums allocated to children of a legal marriage (only $9.1 \%$ of all wealth - and with a noticeable preponderance towards daughters) just over $18 \%$ of sojourner wealth was gifted to offspring born in Asia. The considerably larger share for the latter category reflects the greater incidence of parental responsibilities arising from cohabitation with local women, as well as the important function of wills and testaments as mechanisms for stabilising the boundaries of colonial families. ${ }^{56}$ Far from indicating equitable treatment for mixed-race children, the considerable scale of the financial support consolidated compartmentalisation along geographic, cultural and colour lines. Only 30 wills (7.1\%) made explicit arrangements with respect to education: eight contained instructions for the return of offspring to Europe, while a further nine outlined proposals involving care and schooling plans in India. The remainder simply noted financial provision but did not indicate if this involved relocation to Europe or ongoing residence at the child's place of origin. 57

\section{Family Frictions and Mixed-Race Children}

The constant awareness of the potential for familial friction explains why wills were more likely to contain instructions for an Asia-based upbringing compared to those arranging for children to be sent back to relatives in Scotland or elsewhere in the UK. In his May 1804 will Colonel Alexander Reid of the Madras army, originally from near Dundee, organised his mixed-race son's training at the merchant house of a London-based Scot. In a statement of confidence about the boy's prospects, the substantial sum of $£ 10,000$ was

\footnotetext{
${ }^{55}$ IOR L/AG/34/29/343: Bombay, 20 December 1805; IOR L/AG/34/29/209, 37-41.

${ }^{56}$ Ghosh, Sex and the Family, 107-32.

${ }^{57}$ IOR L/AG/34/29/6 [1789], 17 and 41.
} 
set aside for start-up capital upon completion of his apprenticeship. By contrast, Reid's two mixed-race daughters, Helena and Harriot 'having a predilection for India as their native country' were to remain there, and $£ 625$ and $£ 400$ allocated to their respective educations. ${ }^{58}$ Beneath the benign rationale and optimistic language lay a significant emphasis on notions of 'native' and 'native country' as makers and markers of difference. If Boag and MacMurdo's insistence on genteel acculturation was coded recognition of the obstacles their children might face, Reid's wishes reflected conventional 'Orientalist' and gendered expectations alongside the supposedly greater capacity of London to absorb the colonial 'other.'

In his testament of 1803, Major James MacKerrar from Leith was explicit when issuing instructions regarding his 'natural son,' James Ferguson. After leaving $£ 160$ to 'Bibian Saib,' James's mother, he stipulated that $£ 1,000$ should be reserved for his son's education, adding, the sum 'will be sufficient to bring him up in the best manner in this country, which being the best place for people of his colour and situation, he is not to be sent to Europe but to be brought up to some occupation in this country. ${ }^{59}$ The candour of the observation not only reveals the explicit racialised assumptions at work at the turn of the nineteenth century, but helps explain why a considerable share of wealth outlined in Table 3 went to locally born children. Affection and concern for future wellbeing were undoubtedly important, but the overall dispersal of sojourner wealth underpinned a clear tendency to keep 'Asian' and 'European' families separate.

A key driver of this silo strategy was the interaction of conceptions of colour difference with what Finn describes as 'the frictions' created by the regulation of familial patrimonies.$^{60}$ European individuals migrating to the East Indies understood that parents, siblings, and relations expected them to concentrate on their career and minimise their time in a physically dangerous and culturally alien part of the world. Although more often in hope than in expectation, this strategy would enable profits to be maximised as quickly as possible and returned home to aid the family's financial and social consolidation. ${ }^{61}$ Constant reminders about responsibilities to family reputation and standing and to alleviating debts on ancestral estates were used to regulate the actions of those, Scots included, undertaking the high-risk journey to Asia. ${ }^{62}$ This idealisation of 'home' shaped

\footnotetext{
${ }^{58}$ IOR L/AG/34/29/205, 33-63.

${ }^{59}$ IOR L/AG/34/29/206, 45.

${ }^{60}$ Finn, "Frictions' d'empire," 113-21.

${ }^{61}$ Finn, “Anglo-Indian lives,” 57. See also: IOR L/AG/34/29/14/27; IOR L/AG/34/29/205, 33-63; IOR P/416/90, 24-5.

${ }^{62}$ Kidd, The Forging of Races, 79-120; Glasgow City Archive, Bogle Papers, Bo 19/4, 6-7; NRS, Graham of Kinross, GD

29/2136: Patna, 18 Dec. 1776: Thomas Graham to John Graham, London.
} 
career objectives and became a powerful tool for including or excluded individuals on the basis of their perceived place within the familial unit. ${ }^{63}$ These imperatives limited the willingness of sojourners to admit to any actions that indicated a lessening of their commitment to 'home.' The possibility, and certainly the reality, of relations with local women lay unspoken in much, if not most, of the voluminous correspondence between sojourners and their immediate relations. When such possibilities were aired, it was often between siblings rather than with parents, and it was voiced on a spectrum ranging from euphemistic moralising to explicit injunctions and censorious advice. ${ }^{64}$

In a rare example of a sustained and pointed exchange on the subject, John Cochrane of Rochsoles's letters from 1797 to 1805 to his son, James, a Company civil servant in Madras, reveal how the demands of familial economy drove the emergence of a more innate, rigid, and biological reading of colour and race. ${ }^{65}$ Having learned of James' arrival and successful acclimatisation in Madras, his father noted that 'your [house] garden is, I dare say, a paradise. Beware of an Eve, serpents very often accompany Eves.' While biblical inspired misogyny provided Cochrane with the mode for expressing his disquiet, at its root was the attempt to control his son's sexual practices and steer his financial priorities. In a follow up letter in 1798 , he reminded James of the $£ 4,000$ of debt on the ancestral estate and that income acquisition needed to be the focus of his time in India. He ended his letter by adding; 'And now, my dear James, let me beg you to attend to what Colonel Lyon, I think in a joking way, once said to you, not to send home a parcel of tawny sons or daughters. Cannot you amuse yourself without getting children?' ${ }^{66}$

The mixture of levity and intimacy did little to hide the use of colour as a powerful shorthand for something illegitimate, and that any such children would be alien and unwelcome. The imperatives of family wealth and standing, identified by Finn as enabling the inclusion of mixed-raced children, resulted in this instance as a justification for exclusion. The patterns in Tables 2 and 3 indicate that the thinking typified by John Cochrane's observations shaped the decision of the majority of sojourners to leave their mixed-race children in the place of their birth. In this way they avoided 'friction' and tension with their family at home. Precisely this point was emphasised to James Cochrane by his father in yet another letter. The father's concern was such that he admitted to

\footnotetext{
${ }^{63}$ Gust, Unhomely Empire, 151-3; NRS, Ferguson of Dunfallandie Papers, GD1/398/55: Jallapore, 25 Oct. 1780; NLS, Seaton of Touch, MS19208, fos. 95-101.

${ }^{64}$ Dalrymple, White Mughals, 234-5; NRS, Rossyln Muniments, GD164/1698/5(1-4).

${ }^{65} \mathrm{IOR}, \mathrm{J} / 1 / 15,377-81$.

${ }^{66}$ NRS, Cochrane of Rochsoles, GD1/594/1: Edinburgh, 12 Feb. 1797 and 12 Feb. 1798: John Cochrane to James Cochrane.
} 
consulting with sojourners back from the East Indies and residing in Edinburgh. ${ }^{67}$ After reminding his son of his obligations, John finished with the following advice: 'I certainly hope you excuse me for saying how much I approve the sentiments of a worthy man from India who said that he thought it the duty of every man to provide for what yellow sons and daughters they might have in India but that he also thought they should leave them there, as they always feel but awkward here, and this he had himself done. ${ }^{68}$ The deployment of colour as a natural and widely accepted rationale for placing mixed-race children in geographic, social and cultural silos mirrors the sentiments articulated by MacKerrar. Neither was the tendency to segregate an incidental one; the patterns in Table 3 confirm it was a structural feature of the sojourning economy.

\section{The Proto-Familial State and Racialisation}

Intimate family dynamics and the cultural impact of deepening human, commodity, and commercial contact with Asia lay at the heart of the racialisation of later eighteenthcentury Scotland. Older readings of colour and race, which emphasised cultural, religious and civilizational status, were already hardening into a more explicitly racialist mode in the decades before 1800. In the laird of Rochsoles's logic, no amount of education and integration would remove 'the yellow' features of such children, and so their colour became a convenient absolute, a permanent bar on their prospects and a source of social embarrassment for the family in Scotland. Indeed, the diversity of pejorative terms in private correspondence - 'black', 'yellow', 'tawney' - was matched in official documentations such as wills and testaments by the catch-all and essentialising language of 'native.' The cumulative effect was to embed a heightened awareness of colour difference that worked in tandem with the other factors promoting racialised thinking not just in Asia, but in the day to day thinking of families in Scotland. The manner way in which John Cochrane consulted with a number of returned sojourners provides a window into how such ideas were increasingly prevalent in and transmitted across Scottish society. The combination of concern for family economies and the influence of those with direct experience of Asia helped to normalise new conceptions of race in Scotland by the early 1800s.

\footnotetext{
${ }^{67}$ For early nineteenth-century Edinburgh as the residence for retired EIC employees, see: Ellen Filor, "Death or a pension: Scottish fortunes at the end of the East India Company, c. 1800-57," in The Scottish Experience in Asia, eds. Devine and McCarthy, 129-34.

${ }^{68}$ NRS GD1/594/1: Edinburgh, 21 Mar. 1801: John Cochrane to James Cochrane.
} 
The familial frictions that provided a rationale for the more exclusionary understanding of colour arose in part from the fear that mixed-race offspring would divert income originally intended for return to Europe. Table 3 demonstrates this diversion was a noticeable feature of wealth dispersal, with as much as one pound in five allocated to new family in Asia. This mostly took the form of provision for children, although local women could benefit from the same process. In an example of how ordinary enlisted men often adapted to life in Asia, Sergeant Simon Mackintosh of the $73^{\text {rd }}$ Highland Regiment retired by 1802 to the town of 'Cooty' in the ceded districts of Mysore (now the town of Gooty in present day Andhra Pradesh). While he left $£ 120$ to his father in Scotland, $£ 80$ was reserved for a local-woman residing with him. Similar resource deviation occurred further up the social hierarchy. Despite sojourning to India to relieve the debts on his ancestral estate in Perthshire, Major David Blair of Balthayock's will, dated January 1803 at Colombo, left the considerable sum of $£ 800$ for his two 'natural' children in Pondicherry. Only if they died was the money to be sent to his sisters and used for debt reduction. ${ }^{69}$ The Madras army officer Walter Monteath from Kipp and commissary official, William Campbell from Oban, left sums to Indian mothers and children equal to or greater than amounts left to their families at home. In the case of Huw Stewart, a senior merchant in Benkulen, family in Edinburgh and London were left only $£ 300$ while his three children with a Sumatran woman, 'Inche Rassow' received £12,500. James Clark, a clerk in the Calcutta treasury, even reversed the economic logic of sojourning by insisting in his will of 1791 that income from his assets in Scotland be sent east if necessary, to support 'Nancy' and her two sons by him, Robert and 'Tipoo'. ${ }^{70}$

The retention in Asia of wealth was exactly what fathers, mothers, brothers, sisters, and kin at home hoped to avoid. This scenario constituted a latent fissure inside the familial proto-state. It was also a key determinant that created practical and personal, as opposed to abstract or largely literary and philosophical, reasons for families in Scotland to adopt essentialised, biological and prejudicial attitudes to race and colour. One manifestation of this dynamic can be glimpsed in the pattern by which mixed-race children sent back to Scotland often did not live with their father's family. The trend was not an absolute one, and there were certainly instances where sojourners appointed fathers, brothers, and sisters as guardians in the expectation that they would take responsibility for their offspring. ${ }^{71}$ In an inversion of the usual privileges bestowed on male children by

\footnotetext{
${ }^{69} \mathrm{IOR} \mathrm{L} / \mathrm{AG} / 34 / 29 / 203,44-7$ and 73-8.

${ }^{70}$ IOR L/AG/34/29/201, 74-8 and 80-2; IOR L/AG/34/29/186, 64-7; IOR L/AG/34/29/7 [1792], 31.

${ }^{71}$ IOR P/328/61 [1759], 233-34; IOR L/AG/34/29/7/4; IOR L/AG/34/29/185 [1781], 174-6.
} 
conventional patriarchal thinking, mixed-race daughters were often integrated more successfully. This was especially the case if they arrived in Scotland with fathers willing to invest in their social and material prospects. Major Peter Grant served in the Bengal army from 1765 to 1781 and returned to Edinburgh with his three daughters by a South Asian woman. While one girl predeceased her father, the remaining girls, Jean and Katherine, received the sums of $£ 2,000$ and $£ 1,000$ respectively, substantially more than the $£ 500$ Grant left to his own sister. More practically, their status was consolidated by having ownership rights over their father's landed property at Pilmuir in Haddington (East Lothian) embedded in law. Integration into local society for at least one of these mixedrace women was completed when in 1791 Jean married Alexander Baillie, the estate's leading tenant. ${ }^{72}$ The combined influence of demonstrative commitment from the father, substantial financial resources, and the legitimating aura of landed property helped surmount the social obstacles created by colour or questions of race.

Yet alongside examples of familial inclusion was an equal tendency for children to be placed with extended family or associates. Even the successful assimilation of Mary Munro into her father's Glasgow family began with a distancing strategy that placed her with a clergyman acquaintance. ${ }^{73}$ This solution shielded the sojourner's close relatives from any embarrassment in their social circles and reduced, if not necessarily eliminated, familial frictions. Boag and MacMurdo relied on a brother-in-law and an aunt while the Bengal-based surgeon, Walter Gowdie's options were complicated by the sensitivities of providing for his legal wife and a Bengali woman described as his 'housekeeper.' In his will of 1792 , the first received $£ 750$, and the other, $£ 500$. While the testament was characteristically silent on the nature of the relationship, the scale of the latter gift makes it highly likely that the woman labelled a domestic servant was the mother of the two children mentioned later in the documentation. A further indication is that the arrangement for sending them to Europe did not involve living with Gowdie's legal spouse but placing them in the care of Reverend Francis Scott of West Anstruther in Fife. ${ }^{74}$

Such arrangements speak to the considerable ambivalences and tensions created in Scotland by the existence of new family obligations in India and elsewhere in Asia. The anxieties over family reputations and racial boundaries arising from trans-hemispheric

\footnotetext{
${ }^{72}$ V.C.P. Hodson, List of the Officers of the Army of Bengal, 1754-1834, II (London, 1927), 319; NRS, GD 248/27/4: 23 Aug. 1785, 'Memorial of children of Major Peter Grant of E.I.C.'; NRS, CC8/8/126: Major Peter Grant, Edinburgh Commissary Court, 1368-74; NRS, Registers of Seisins (Printed Abridgements), Haddington, (537), (1770-71).

${ }^{73}$ Finn, “Anglo-Indian lives," 60-61.

${ }^{74}$ IOR L/AG/34/29/8 [1793], 10.
} 
migration are exemplified in the 7 December 1780 will of Duncan Campbell. ${ }^{75}$ The son of an excise officer from Perth, Campbell had served since 1762 as the Company's surgeon at Fort Marlborough in Benkulen in Indonesia. It is clear from his testament that he made a considerable amount of money, allocating $£ 5,750$ to family members and friends. ${ }^{76}$ Campbell's long-distance mobility found an echo in the global dispersal of his fortune. He left $£ 700$ to his two nephews working on slave-plantations in Grenada, evidence of how families from lower-middling social backgrounds combined migration and kinship to construct networks that spanned both the Atlantic and Indian Oceans. ${ }^{77}$ To such global connectivity can be added the important gendered dimension which shaped the distribution of other family fortunes. A sister in Dunkeld and in Blair Atholl each received $£ 250$. As was the case with other testaments, colonial profits seeped back into locales far from the imperial metropole and sustained the status of women at the margins of the genteel social order.

Duncan's life in Benkulen also intersected with questions of mixed-race relationships and the forms of slavery practiced in Asian societies. ${ }^{78}$ His cohabitation with a local woman was disguised using the usual rhetorical and bureaucratic tactics. These involved a delicate balancing act between legal acknowledgement and the downplaying of the financial, familial, and racial consequences arising from such liaisons. The use of the diminutive European name, 'Fanny,' and the foregrounding of her domestic function masked the Sumatran woman's identity and her central place in Campbell's household. Fanny was left a smaller amount than family in Scotland. However, she did receive the sum of $£ 150$, ownership of four slaves, and the use of paddy fields near Fort Marlborough for the remainder of her life. By far and away the largest bequest consisted of $£ 3,250$ (later increased to £5,000), which was assigned for the 'welfare and education' of Margaret, Duncan and Fanny's 'reputed natural daughter.' Like her father's fortune, Margaret, too, crossed from Asia back to Europe, but she did so in manner that confirms the social distancing and displacement faced by mixed-race children. At some point after Campbell's death, Margaret was sent to Scotland, where her trustees established a residence for her in Aberdeenshire. Her father's family in Perthshire were content for her to be placed at a deliberate distance. Margaret lived off the interest on $£ 5,000$ loaned from

\footnotetext{
${ }^{75}$ NRS GD113/3/581; IOR B/78, 46.

${ }^{76}$ National Archive, Kew [NA], PROB 11/1091, 243-4; IOR L/AG/34/29/186, 64-7.

${ }^{77}$ Both Campbell's nephews were employed on Caribbean plantations owned in this period by Scots. See: University College of London, Legacies of British Slave-ownership. https://www.ucl.ac.uk/lbs/estates/ [Accessed: 7 Dec. 2021]

${ }^{78}$ Indrani Chatterjee, "Renewed and connected histories: Slavery and the historiography of South Asia," in Slavery and South Asian History, eds. Indrani Chatterjee and Richard M. Eaton (Bloomington: Indiana University Press, 2006$), 20-1$.
} 
her father's fortune to a gentry family with connections to the Madras army. The arrangement lasted until she died on 8 November 1789, an event which resulted in the registration of her affairs at the commissary court of Aberdeenshire. ${ }^{79}$ While her life story, like that of the Grant sisters, was preserved in court records in unusual detail, Margaret's experience of geographic displacement and familial rejection reveals how racialised thinking manifested itself in later eighteenth-century Scotland.

The change in perceptions of race and colour over the last quarter of the eighteenth century was gradual and overlapped with pre-existing stadial and biblically derived understandings. However, the lived experience and challenges of the 'familial proto-state' in India facilitated attitudes which stressed the innate, unchanging qualities of 'white' and non-white origins. This new racialist tone was evident both among sojourners in India and their families and friends in Scotland. The Bengal civil servant David Anderson was a close associate of Warren Hastings, the leading administrative figure from the era of the Company's early raj believed by some historians to exhibit a relative respect for South Asia's cultures and people. ${ }^{80}$ Despite his involvement in 'Orientalist' modes of governance, Anderson's own circle of friends deployed explicit languages of colour in a tellingly causal manner. In a letter of June 1783 from Calcutta offering congratulations on David's safe return and the purchase of an estate in East Lothian, Claud Alexander, originally from Renfrew, queried aspects of the homecoming. ${ }^{81} \mathrm{He}$ joked about Anderson's failure to terminate his financial obligations to a Bengali woman, adding: 'Butchwah is behaving very well but it is impossible her child can have been begot by you. It has not a feature of your face and exceedingly dark and ill looking, it is at least three shades darker than herself. I wonder that you keep her starving here when you have another, you should lay her six or eight hundred rupees and tell her to shift for herself. ${ }^{82}$ The easy, mocking deployment of colour and the dismissive tone are testimony to how normative exclusionist ideas of race had become, even by the 1780s. Neither were such attitudes the preserve of those with direct, personal experience of Asia. The human, migratory, familial, and financial links that now connected that part of the world to Scottish society meant the same prejudicial emphasis on essentialised difference featured in the thinking of those who never ventured to the East Indies. The example of John Cochrane not only exemplifies the role of friction in familial economies, his pleas to his

\footnotetext{
${ }^{79}$ NRS Aberdeen Commissary Court, CC1/6/59, 16528-37; NRS Register of Sasines (Printed Abridgements), Angus [176].

${ }^{80}$ Marshall, The Making and Unmaking, 226.

${ }^{81}$ IOR J/1/6, 430-33; IOR J/1/8, 292-3; IOR B/82, 255-6, 266; IOR B/87, 354-5, 401; NRS Register of Sasines (Printed Abridgements), Haddington (57); NRS, SC36/48/6, 275-7.

${ }^{82}$ NRS Boyd Alexander Papers GD393/6/1, fo. 109: Calcutta, 9 June 1783: Claud Alexander to David Anderson.
} 
son in Madras confirm that racialised thinking was firmly rooted in Scottish society. Having attempted repeatedly to shape his son's social and personal relations from afar, he reiterated that alongside securing the ancestral estate his key wish was that 'I shall see a white heir of your own legal begetting. ${ }^{93}$

\section{CONCLUSION}

The increasing number of Scots in the EIC during the eighteenth and early nineteenth centuries was a manifestation of processes of trade, migration and colonisation that defined the era of proto-globalisation from c. 1500 to c. $1800{ }^{84}$ This Scottish presence should not be overly disentangled from the wider British, Irish and European colonial communities. Scots were highly integrated into the Company's various sectors and helped to alter and complicate the composition of the workforce as a result. ${ }^{85}$ While a small numeric presence if viewed in the context of the large population centres of the IOW, the networking patterns, financial priorities, and cultural assumptions exhibited by Scots are useful windows into the social and ideological character of the Company's early colonial regime. Arriving in Asia from the 'provincial' regions of the British and Irish Isles, they cast light upon the practical and cultural consequences of the familial proto-state. Kinship and family links emerge strongly from Scottish wills and reinforce interpretations that stress the private and unofficial drivers of British colonialism in this period. The testaments of those such as George Taylor, John MacKenzie, William Balfour or Duncan Campbell might seem little more than a series of separate life stories. Yet their individualised nature speaks to the importance of personal and social agendas at the heart of the Company's colonial order in India and elsewhere. The central role of these economies of family and kinship raises questions about the boundaries and interactions between Europe and Asia in the pre-1800 era. The two hemispheres were connected through a dense web of informal networks as well as by the formal institutions of colonialism and their associated financial and commodity flows.

Given the small number of sojourners departing at any one time for Asia, the impact of these linkages was surprisingly widespread in both a geographic and social sense. As a part of the British and Irish Isles which remained relatively underdeveloped and lacking in liquidity compared to its richer neighbour, Scottish society exploited the 'familial proto-

\footnotetext{
${ }^{83}$ NRS GD 1/594/1-3: Edinburgh 12 Feb. 1798: John Cochrane to James Cochrane.

${ }^{84}$ Kenneth Pomeranz, The Great Divergence: China, Europe and the making of the modern world economy (Princeton: Princeton University Press, 2000), 192-206; Hopkins, "The history of globalisation," 25-8.

${ }^{85}$ Marshall, "British society in India under the East India Company," 90-1, 101.
} 
state' of the early Company raj to secure substantial transhemispheric remittances. ${ }^{86} \mathrm{Wills}$ and testaments demonstrate that material profits arrived back in all of the country's different regions and among all its social classes, influencing gender hierarchies and familial prospects in the process. These legal and financial legacies of human mobility show how Asia's impact extended well beyond intellectual trends in Orientalism, or developments in mass commodity consumption, country house culture, and the shaping of genteel tastes. ${ }^{87}$ Localities as diverse as Edinburgh, Markinch, and Assynt witnessed personnel and wealth arrive back in ways that transformed family resources and lived experiences. The conventions that shaped the distribution of sojourning wealth reinforced patriarchy while enhancing the financial and social status of women. These ambiguous social dynamics underline the extent to which influences from Asia seeped into the structures of family life. In this way, the effect of the IOW appears more quotidian, pervasive and significant, even at the north western edge of Europe.

However positive these oceanic links on Scotland may have been in a financial sense, they also generated significant tensions. Assessments to date of the familial protostate argue that perceptions of social respectability could under certain conditions surmount negative attitudes to mixed-race children. The evidence from Scottish wills and testaments provides some limited supporting evidence for this interpretation but points more consistently to a set of segregationist cultural reactions and practices. Asian women experienced arrangements with European sojourners that ranged from domestic enslavement, exploitative concubinage, to affective and sensitive relationships. The amount of wealth these women received was decidedly marginal when set against the prioritising of family in Scotland.

The treatment of mixed-race children was more ambiguous still but followed the same tendency towards marginalisation. Set against individual cases such as that of the Munros of Glasgow or the daughters of Major Peter Grant, lay a broader pattern of placing offspring in geographic silos and cultural compartments. When sojourners died or returned home the more usual practice involved leaving children in Asia or, if they were sent to Europe, placing them outside immediate family circles. This distancing strategy points to the underappreciated influence of India and Asia more generally in shaping

${ }^{86}$ C.A. Whatley, Scottish Society, 1707-1830: Beyond Jacobitism, towards industrialisation (Manchester: Manchester University Press, 2000), 72.

${ }^{87}$ Jan de Vries, "Understanding Eurasian trade in the era of the trading companies," in Goods from the East, 1600-1800: Trading Eurasia, eds. Maxine Berg, Felicia Gottman, Hanna Hodacs and Chris Nierstrasz (Basingstoke: Palgrave MacMillan, 2015), 7-39; Margot Finn and Kate Smith, "Introduction," in The East India Company at Home, 1757-1857, eds. Margot Finn and Kate Smith (London: University College London Press, 2018), 1-16. 
attitudes in Scotland towards questions of colour and the shift towards ever more overtly racialist thinking. This meant the IOW supplemented the Atlantic World and Enlightenment dynamics at work in Scottish society. All these factors meant intellectual and social trends moved towards more essentialised, inflexible readings of race. ${ }^{88}$

In this context, the testaments of Scottish sojourners can be read as acts of cultural navigation around the fluid boundaries of family, race and belonging. The process involved the distribution of monetary fortunes and the revealing of troubling new additions to the family. The result was that for many fathers, mothers, sisters, brothers and other relatives, Asia was never a distant or disconnected part of the world. It was never just an abstract, a part of the Empire to be understood in terms of commodities, debates around luxury, or stereotyping of the Orient. It intruded directly, immediately and in often unnerving ways into deeply personal family affairs and even influenced how kin groups conceived of themselves. Faced with this pressure, increasingly rigid understandings of colour and racial difference helped shore up the policing of familial wealth and identities. This marked an important additional factor driving the racialisation of Scotland, and indeed the rest of Britain and Ireland, in the second half of the eighteenth century. Concepts of race and colour were never just a matter of Enlightenment narratives or abstract philosophical debates on the nature of human progress. Attitudes were also shaped by lived experience and by mundane material and social anxieties among family and kin in Scotland. The origins and geographies of racialisation were multi-centred. These ideas developed among sojourners with direct experience of the East Indies, such as Claud Alexander, or Major MacKerrar, and in the mind-set of individuals such as John Cochrane who never left Scotland. One of the most significant conclusions to be drawn from the wills of Scots in Asia is a clearer understanding of the surprisingly personal and even intimate dynamics that drove the development of racialist thinking in Europe during the age of enlightenment and empire.

${ }^{88}$ Colin Kidd, "Teutonist ethnology and Scottish Nationalist inhibition, 1780-1880," The Scottish Historical Review, 74 (1995), 48-50; Sebastiani, The Scottish Enlightenment, 163-67. 